Relations industrielles

Industrial Relations

\title{
“An umbrella full of holes?”
}

Corporate Restructuring, Redundancy and the Effectiveness of ICE Regullations

\section{Un parapluie percé ?}

Restructurations d'entreprise, licenciements et efficacité de l'application au Royaume-Uni de la Directive européenne sur l'information et la consultation des travailleurs

\section{¿“Un paraguas lleno de huecos”?}

\section{Restructuración empresarial, reducción de personal y eficacia de las regulaciones ICE}

\section{Phil Taylor, Chris Baldry, Andy Danford et Paul Stewart}

Volume 64, numéro 1, hiver 2009

URI : https://id.erudit.org/iderudit/029537ar

DOI : https://doi.org/10.7202/029537ar

Aller au sommaire du numéro

Éditeur(s)

Département des relations industrielles de l'Université Lava

ISSN

0034-379X (imprimé)

1703-8138 (numérique)

Découvrir la revue

Citer cet article

Taylor, P., Baldry, C., Danford, A. \& Stewart, P. (2009). "An umbrella full of holes?”: Corporate Restructuring, Redundancy and the Effectiveness of ICE Regulations. Relations industrielles / Industrial Relations, 64(1), 27-49.

https://doi.org/10.7202/029537ar

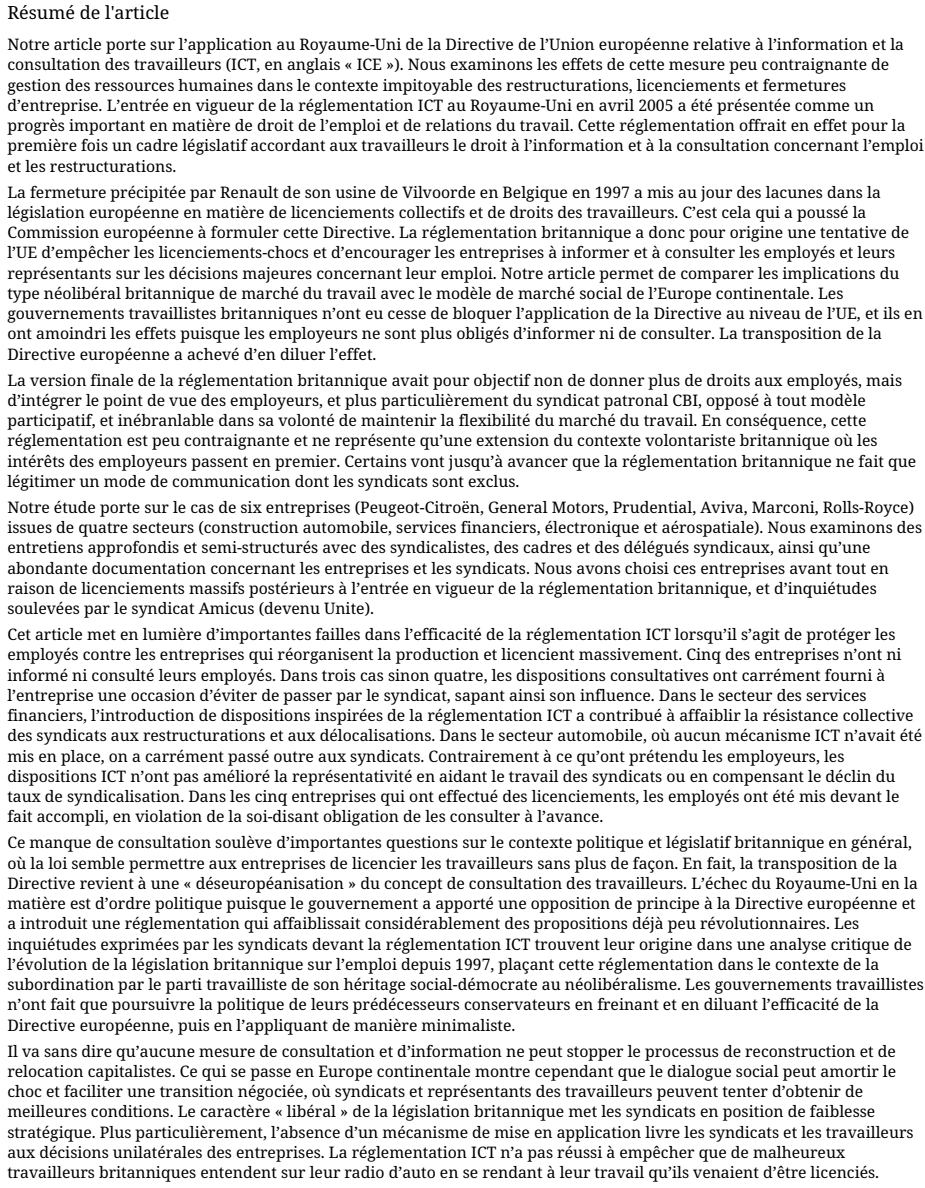

Résumé de l'article

Notre article porte sur l'application au Royaume-Uni de la Directive de l'Union européenne relative à l'information et la consultation des travailleurs (ICT, en anglais « ICE »). Nous examinons les effets de cette mesure peu contraignante de gestion des ressources humaines dans le contexte impitoyable des restructurations, licenciements et fermetures d'entreprise. L'entree en vigueur de la reglementation ICT au Royaume-Uni en avril 2005 a eté presentee comme un première fois un cadre législatif accordant aux travailleurs le droit à l'information et à la consultation concernant l'emplo et les restructurations.

La fermeture précipitée par Renault de son usine de Vilvoorde en Belgique en 1997 a mis au jour des lacunes dans la Commission européenne à formuler cette Directive. La réglementation britannique a donc pour origine une tentative de l'UE d'empêcher les licenciements-chocs et d'encourager les entreprises à informer et à consulter les employés et leurs représentants sur les décisions majeures concernant leur emploi. Notre article permet de comparer les implications du type néolibéral britannique de marché du travail avec le modèle de marché social de l'Europe continentale. Les gouvernements travaillistes britanniques n'ont eu cesse de bloquer l'application de la Directive au niveau de l'UE, et ils en ont amoindri les effets puisque les employeurs ne sont plus obligés d'informer ni de consulter. La transposition de la Directive européenne a achevé d'en diluer l'effet.

La version finale de la réglementation britannique avait pour objectif non de donner plus de droits aux employés, mais d'intégrer le point de vue des employeurs, et plus particulièrement du syndicat patronal CBI, opposé à tout modèle participatif, et inébranlable dans sa volonté de maintenir la flexibilité du marché du travail. En conséquence, cette réglementêtation est peu contraignante et ne représente qu'une extension du contexte volontariste britannique où les légitimer un mode de communication dont les syndicats sont exclus.

Notre étude porte sur le cas de six entreprises (Peugeot-Citroën, General Motors, Prudential, Aviva, Marconi, Rolls-Royce) issues de quatre secteurs (construction automobile, services financiers, électronique et aérospatiale). Nous examinons des entretiens approfondis et semi-structurés avec des syndicalistes, des cadres et des delégués syndicaux, ainsi qu'une abondante documentation concernant les entreprises et les syndicats. Nous avons choisi ces entreprises avant tout en raison de licenciements massifs postérieurs à l'entrée en vigueur de la réglementation britannique, et d'inquiétudes soulevées par le syndicat Amicus (devenu Unite).

Cet article met en lumière d'importantes failles dans l'efficacité de la réglementation ICT lorsqu'il s'agit de protéger les employes contre les entreprises qui réorganisent la production et licencient massivement. Cinq des entreprises n'ont informé ni consulté leurs employés. Dans trois cas sinon quatre, les dispositions consultatives ont carrément fourni à l'entreprise une occasion d'éviter de passer par le syndicat, sapant ainsi son influence. Dans le secteur des services financiers, l'introduction de dispositions inspirées de la réglementation ICT a contribué à affaiblir la résistance collective des syndicats aux restructurations et aux delocalisations. Dans le secteur automobile, où aucun mécanisme ICT n'avait éte mis en place, on a carrement passé outre aux syndicats. Contrairement à ce qu'ont prétendu les employeurs, les

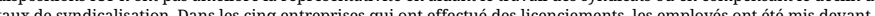
ait accompli, en violation de la soi-disant oblietion de les consulter à l'avance.

Ce manque de consultation soulève d'importantes questions sur le contexte politique et législatif britannique en général, ou la loi semble permettre aux entreprises de licencier les travailleurs sans plus de façon. En fait, la transposition de la matière est d'ordre politique puisque le gouvernement a apporté une opposition de principe à la Directive européene a introduit une réglementation qui affaiblissait considérablement des propositions déjà peu révolutionnaires. Les inquiétudes exprimées par les syndicats devant la réglementation ICT trouvent leur origine dans une analyse critique l'évolution de la législation britannique sur l'emploi depuis 1997, plaçant cette réglementation dans le contexte de la subordination par le parti travailliste de son héritage social-démocrate au néolibéralisme. Les gouvernements travaillistes n'ont fait que poursuivre la politique de leurs prédécesseurs conservateurs en freinant et en diluant l'efficacité de la Directive européenne, puis en l'appliquant de manière minimaliste.

Il va sans dire qu'aucune mesure de consultation et d'information ne peut stopper le processus de reconstruction et de relocation capitalistes. Ce qui se passe en Europe continentale montre cependant que le dialogue social peut amortir le choc et faciliter une transition négociée, où syndicats et représentants des travailleurs peuvent tenter d'obtenir de meilleures conditions. Le caractere " libéral " de la législation britannique met les syndicats en position de faibless stratégique. Plus particulièrement, l'absence d'un mécanisme de mise en application livre les syndicats et les travailleurs aux décisions unilaterales des entreprises. La réglementation ICT n’a pas reussi a empêcher que de malheureux travailleurs britanniques entendent sur leur radio d'auto en se rendant à leur travail qu'ils venaient d'être licenciés.

Tous droits réservés (C) Département des relations industrielles de l'Université Laval, 2009
Ce document est protégé par la loi sur le droit d'auteur. L’utilisation des services d'Érudit (y compris la reproduction) est assujettie à sa politique d'utilisation que vous pouvez consulter en ligne.

https://apropos.erudit.org/fr/usagers/politique-dutilisation/ 


\title{
"An umbrella full of holes?"
}

\section{Corporate Restructuring, Redundancy and the Effectiveness of ICE Regulations}

\author{
Phil Taylor, Chris Baldry, Andy Danford and Paul Stewart
}

This article concerns the manner in which the European Union Information and Consultation of Employees (ICE) Directive has been implemented in the UK in the harsh corporate conditions of restructuring, redundancy and site closure. Drawing on interview and documentary evidence from six case companies (Peugeot-Citroën, General Motors, Prudential, Aviva, Marconi, Rolls-Royce), the article exposes major fault lines in the effectiveness of the UK's ICE Regulations to provide even limited protection for employees who were presented with redundancy as a fait accompli. Contrary to management claims, ICE arrangements have not provided additional levels of representation either to complement unions or to fill the "representation gap" left by declining coverage. The failure to consult raises broader questions on the wider political and legislative environment in the UK.

KEYWORDS: European Union, information and consultation of employees, UK, plant closure

\section{Introduction}

This article concerns the manner in which the European Union (EU) Information and Consultation of Employees (ICE) Directive has been implemented in the UK. The evidence presented here raises significant questions over the intentions and behaviour of UK firms regarding the ICE Regulations. We take what on the surface seems to be a benign, even innocuous, HR-related public policy imperative and test its benefit and utility in the harsh and conflict-ridden corporate circumstances of restructuring and large-scale redundancy. Data from six case study companies challenges the optimism that accompanied the statutory implementation in the UK of the ICE Regulations in April 2005. ${ }^{1}$

At the outset it is necessary to provide some background to the ICE Regulations. Enactment was widely heralded as being an important development in UK employment law that would have considerable significance for industrial relations (Hall, 2006). The Trades Union Congress (TUC) exemplified the conviction that positive outcomes

Phil Taylor is Professor of Work and Employment Studies at the Department of Human Resource Management, University of Strathclyde, Glasgow, UK (philip.taylor@strath.ac.uk). 
would follow for employee representation and union organization. Indeed, the TUC claimed that the ICE Regulations could lead "to the biggest change in workplace relations for a generation" (Hall, 2005: 103). Such optimism was rooted in the fact that the Regulations established for the first time in the UK a statutory framework giving employees the right to be informed and consulted by their employers on a range of business, employment and restructuring issues.

The existing literature on the ICE Regulations, notably that by Hall $(2005 ; 2006)$ and Hall and Terry (2004), provides an excellent platform for understanding the purpose, nature and detail of the Regulations. This work has delivered valuable insights into the anticipated and initial responses of both employers and unions. Nevertheless, in such early attempts to offer an "interim assessment" of the ICE Regulations, the tenor understandably has been speculative and the conclusions necessarily provisional (Hall, 2006). Three years after enforcement, though, we are better placed to marshal empirical evidence on outcomes.

The intention here is not to offer a comprehensive evaluation of the ICE Regulations in respect of the extent of coverage, the detail of arrangements and so on, but rather to alter the prism through which their efficacy is evaluated. Arguably, a principal measure of the Regulations' value should reside in their effectiveness in conditions of restructuring, redundancy and site closure. It should be recalled that it was Renault's precipitate closure of the Vilvoorde plant in Belgium in 1997, exposing loopholes in national legislation and the European regulatory framework on collective redundancy and worker rights, that prompted the European Commission (EC) to formulate the ICE Directive (http:// www.eurofound.europa.eu/eiro/1997/03/feature/be9703202f.html). Thus the existing UK Regulations originated in the EU's attempt to prevent "shock" redundancies and to ensure that employees and their representatives would be informed and consulted on major decisions affecting the security and conditions of their employment. The intention was to create a regulatory framework in which they might be able to influence outcomes through presenting alternatives to company proposals.

Conceptually, this paper presents an interesting opportunity to contrast the assumptions and consequences of the neo-liberal labour market model currently held by the UK with the "Social Market" model of continental Europe. The long history of statutory employee rights in most European states was integrated and made a key plank in the formation of the Single European Market in 1992. The Maastricht Treaty setting up the Single Market had included a Social Chapter covering areas such as employment security, health and safety, working time and rights to information and consultation (Ramsay, 1991). EU policy thinking was that, firstly, a single market in labour should be based on a harmonization of employment conditions and secondly, that competition within Europe should be tempered by a concern with the employment and social conditions of Europe's citizens (Addison and Siebert, 1992; Baldry, 1994; Streeck, 1994). What this has meant in practice is, not that there have been no collective redundancies, but that it is more usual for employee representatives (through the unions or works councils) to be jointly involved in discussions ("social dialogue" in EU terminology) over how the redundancies or closures are to be handled, the terms of compensation and support for finding alternative employment. 
British governments, with no prior history of positive employment rights, distanced themselves wherever possible from such thinking, even refusing, under the Conservatives, to sign the Social Chapter (Cressey, Gill and Gold, 1997). For the past decade British Labour Governments, firmly embracing a neo-liberal agenda, have themselves implicitly contrasted the benefits to employers of Britain's "flexible labour market" with the perceived rigidities of more highly regulated EU member states such as France and Germany (Barnard, Deakin and Hobbs, 2003). Essentially, and as seen by the unions, this comes down to the fact that it has been much easier and cheaper to make collective redundancies in Britain than in other EU countries. Thus the ICE Regulations were seen by the TUC and its affiliates as offering some hope that, as with health and safety and working time, some aspects of Social Europe would be imported to the UK, to their members' benefit.

In this article, using a case study methodology, we examine the role which the ICE Regulations played during the process of restructuring and redundancy in four UK employment sectors and show that their efficacy in ameliorating redundancy has been extremely limited. The research on which this paper is based was prompted by trade union (specifically Amicus ${ }^{2}$ ) concerns regarding the apparent inability of the UK's Regulations to protect members from corporate restructuring and the unilateral exercise of managerial prerogative. Evidence is evaluated from six case study companies of both historical and contemporary significance to the UK economy: motor vehicle manufacturing (Peugeot-Citroën, General Motors), financial services (Prudential, Aviva), electronics (Marconi) and aerospace/engineering (Rolls-Royce). Case selection was stimulated largely by the incidence of significant job loss ${ }^{3}$ since the Regulations' enactment. Principal lines of inquiry included: the extent to which companies pre-empted the Regulations and established Information and Consultation prior to April 2005; the nature of arrangements, if any, subsequently introduced; and the implications for the processes and substance of collective bargaining following enactment, particularly where new ICE arrangements were established. Finally, there were questions regarding the impact of the Regulations on employers' actions and, crucially, of the extent to which employees and unions were informed of, and involved in consultation over, corporate restructuring proposals.

The article is structured, first, to provide synopses of the EU Directive and, following transposition, of the UK's Regulations, indicating potential weaknesses for workers and unions. A brief explication of research methods and data sources is followed by an evaluation of the empirical evidence. The two motor manufacturing cases are considered together, as are those in financial services, while those in electronics and aerospace/engineering are assessed separately. The evidence is unequivocal that employers failed to inform and consult, contradicting the rhetoric surrounding the ICE Regulations and the intention of the I \& C Directive. The fact that decisions to effect redundancies were effectively a fait accompli challenges optimistic expectations that the Regulations would expand union and employee influence over corporate decision-making. We conclude with general observations relating the information and consultation provisions to Labour's employment legislation framework as dominated by the influence of neo-liberalism (Smith and Morton, 2006). 


\section{The EU Information and Consultation of Employees' Directive}

The UK's ICE Regulations derived from the EC Directive on Information and Consultation in the Workplace, which required Member States to establish "a general framework setting out minimum requirements for the right to information and consultation" (Article 1), ensuring that employers consult employees over potential changes in their employment. Article 4 laid out employers' obligations on information provision which included: recent and probable development of an undertaking's (or establishment's) economic situation; the situation, structure and probable development of employment or anticipatory measures, particularly where there are threats to employment; decisions likely to lead to substantial changes in work organization or contractual relations; information to be provided timeously to enable employees' representatives to prepare for consultation (Hayes, 2004). Consultation requirements included enabling employee representatives to meet with the employer, who must provide responses to opinions they might formulate, with a view to reaching agreement on decisions likely to lead to substantial changes in work organization or contractual relations. Significantly, Article 5 emphasized that practical arrangements were to be defined and implemented by Member States in accordance with their national law and industrial relations practice. Similarly, Member States would determine the "adequate" administrative or judicial procedures, appropriate measures in the event of non-compliance and "effective, proportionate and dissuasive" penalties in circumstances of the infringement of the Directive (Article 7).

Several critical observations can be made of these objectives. Firstly, despite the apparently unambiguous prescription of employees' rights, there is, as in other EU Directives (for example the Directive on Working Time), little structural detail about what amounts to a set of general objectives. Secondly, the I \& C Directive essentially does not embrace co-determination (Smith and Morton, 2006: 409) and marks a further shift along the participation spectrum from those conceptions of industrial democracy based on worker rights to softer employer-led forms of employee involvement (Blyton and Turnbull, 2004; Hall and Marginson, 2005; Hyman and Mason, 1995). Thirdly, given the latitude accorded Member States in determining arrangements, the transposition process can prove additionally decisive in determining any Directive's impact.

\section{UK Government, the ICE Directive and Regulations}

From the outset, the UK Labour government threatened to stymie the I \& C Directive's promise "to fill the gaps and counter the shortcomings ... in the employee information and consultation provisions" (Memorandum accompanying Draft Directive, 1998). Labour opposed the attempt to overcome this statutory deficit, ${ }^{4}$ consistently blocking the I \& C Directive's introduction (Labour Research, 2000), arguing that it would "cut across existing practices in member states to no benefit" and was "difficult to reconcile with subsidiarity" (Hall, 2005: 108). It was only after the dissolution of the "blocking minority" (Denmark, Germany, Ireland, UK) that the UK government 
abandoned its opposition in principle, leading ultimately to the Directive's adoption in 2002 (Hall et al., 2002). Subsequently, the government was prominent in successful attempts to dilute the original draft Directive by removing the obligation on employers to inform and consult, and widening the scope given to social partners to negotiate arrangements. It also omitted the Commission's proposed approach to sanctions for non-compliance, under which the "legal effect of restructuring decisions taken by employers in serious breach of their information and consulting obligations would be suspended" (Hall, 2005: 108).

Transposition produced further dilution. Significantly, the government prefaced discussions on the proposed Regulations with a distinct set of political-economic values and assumptions. Specifically, the Department of Trade and Industry (DTI) advocated a version of ICE predicated, not on extending employee rights, but on advocacy of the "High Performance Workplace" (DTI, 2002), linking economic success to employee involvement. This amounted to a straightforward HRM position in which enhanced consultation creates a climate of trust, which induces greater commitment to an organization's goals and thus improves performance. However, for the employers' body, the Confederation of British Industry (CBI), even a modest commitment to employee involvement went too far $(C B I, 2002)$. In rejecting the claim that ICE was necessary for improved performance, it restated its opposition to any kind of European stakeholder model and to the UK government's commitment to partnership. Its preference was for direct consultation that excluded employee representatives or trade unions. These were preconditions for maintaining the "strength" of the UK's flexible labour markets. Reflecting the pressure to adopt minimalist principles, a further document (DTI, 2003) established parameters for concluding consultation with the $\mathrm{CBI}$ and TUC. The outcome was an agreed framework, which differed little from the final version of the ICE Regulations. ${ }^{5}$

Although constraints of space prohibit detailed analysis, it is necessary to emphasize some implications arising from the main provisions. Most importantly, the government delivered maximum flexibility for employers who are not obliged to conform to the sprit of the original I \& C Directive. Rather the Regulations' "trigger mechanisms" permit employers not to act unless $10 \%$ of employees request negotiations on an I \& C agreement. In a similar vein, and responding to the CBI's appeal for managerial discretion, the government encouraged parties "to develop their own arrangements tailored to their particular circumstances though voluntary agreements" (ACAS, 2004). The expectation was that employers would prefer the voluntary Previously Existing Agreements (PEA) route, which provided numerous advantages over negotiated agreements and standard provisions, not least the fact that PEAs are not legally binding, have no remedy at the Central Arbitration Committee (CAC) and can be concluded at any point before the date of a valid employee request to initiate negotiations. PEAs assist employers in "effectively pre-empting the use of the Regulations' statutory procedures (significantly higher thresholds of employee support being required to trigger new negotiations where undertakings have PEAs in place)" (Hall, 2006: 459-460). Even when the statutory negotiating procedure is invoked, the I \& C Regulations stress the importance of enterprise-specific agreements. 
The Regulations are non-prescriptive concerning the terms of either PEAs or negotiated agreements. Diverse outcomes are possible, including the company council, Joint Consultative Committee model, or union-based arrangements. While no explicit reference was made to direct forms of information and consultation, they were implicitly conceded since, "The parties to a negotiated agreement will be able to agree the information and consultation arrangements that best suit their needs and agreements" (Hall, 2005: 110). Nor do the Regulations accord specific statutory rights to unions, which have been "written out of the script" of the standard I \& C provisions under which representatives must be directly elected by workplace ballot. Of course, unions do have potential roles: negotiating and approving PEAs, acting as negotiating reps (albeit at the employer's discretion) and standing as candidates for I \& C bodies. Further, the Regulations offer unions the chance of gaining footholds as elected I \& C representatives in non-recognized areas (Labour Research, 2004). Consequently, unions generally welcomed the Regulations as contributing to the democratization of the workplace or at least to creating more socially responsible employer-employee agendas. Yet fears existed that ICE would deliver only post facto information about company intent or would undermine collective agreements "by setting up separate workplace councils for information and consultation" (Unison, 2005). For many, "the jury is still out" and it is only through case law and concrete experience that the cautious expectations will be tested.

Academic commentary overall is less sanguine. Davis and Kilpatrick believe that the Regulations have "disconnected union-based structures from the representative structures of information and consultation" (2004: 141), giving statutory support to a second channel of communication from which unions are excluded, even where they are recognized or possess members. For Smith and Morton (2006: 409) this is unprecedented and contrasts markedly with existing issue-specific statutory consultation, by allowing employers to determine the boundaries of I \& C procedures to fill the "representation gap." Further, as Moore, McKay and Bewley (2004: 82) argue, employer-dominated consultative bodies may weaken or displace union organization. As a prime example of "reflexive" employment law (Hall, 2006), where legislation promotes voluntary adjustments to the employment relationship, employer interests would always dominate. Indeed, so employer-friendly were the Regulations that the $\mathrm{CBI}$ could celebrate the fact that the government had "made sense of a poor piece of EU legislation" (Hall, 2005: 103).

\section{Methods, Sources, Case Profiles}

Thirteen semi-structured interviews, designed to achieve consistency in data acquisition and analysis, were conducted with full-time trade union officers, senior representatives and shop stewards between September 2006 and January 2007. Interviews lasted between 45 minutes and two hours and were recorded and transcribed. This evidence was complemented by company documentation, including feasibility studies, restructuring proposals, annual reports and ICE arrangements. Diverse union data-media briefings, members' communications, alternative business plans, and correspondence-were collated and evaluated. 
In addition, organizational contextual analysis is rooted in longitudinal case study research completed at five of the six firms. At Rolls-Royce Bristol the researchers have tracked changes in work organization, industrial relations practices and staff consultation processes over a nine-year period. Over this time the work has involved multiple site visits, questionnaire surveys of shop stewards and workers, interviews with sixteen senior managers and line managers, eight convenors, twenty shop stewards, fifty manual and non-manual workers and two full-time regional officers (Danford et al., 2002; 2003; 2004; 2005). At GM-Vauxhall, a similar longitudinal approach over a period of fourteen years was supplemented with recent interviews of convenor and deputy convenor, four stewards and two full-time officers (Amicus and TGWU) on the impact of ICE during the jobs crisis of May-June 2006 (Danford et al., 2008; Stewart et al., 2008). For more than a decade, one team member has conducted research in the financial services sector, notably in relation to organizational restructuring and the re-configuration of interactive service work in the form of call centres and the outcomes for employment relations and participation (Bain and Taylor, 2002; Taylor and Bain, 2001). Latterly, studies have considered the manifold consequences for employment levels and union representation arising from the growth of offshoring (Bain and Taylor, 2008; Taylor and Bain, 2005; 2006; 2008). Prior to examining the empirical evidence, we present summary profiles of the case companies (Table 1).

\begin{tabular}{|c|c|c|c|c|c|c|}
\hline \multicolumn{7}{|c|}{$\begin{array}{l}\text { TABLE } 1 \\
\text { Profiles of Case Companies }\end{array}$} \\
\hline Company & $\begin{array}{l}\text { Bargaining } \\
\text { Arrangements/ } \\
\text { Recognition }\end{array}$ & $\begin{array}{l}\text { Union } \\
\text { Density }\end{array}$ & Union(s) & $\begin{array}{l}\text { ICE } \\
\text { Initiatives }\end{array}$ & $\begin{array}{l}\text { Name of IC } \\
\text { Body }\end{array}$ & $\begin{array}{l}\text { Restructuring/ } \\
\text { redundancy }\end{array}$ \\
\hline Peugeot-Citroën & Full CB & $95 \%$ & $\begin{array}{l}\text { Amicus/ } \\
T \& G\end{array}$ & $\mathrm{No}^{*}$ & $\mathrm{n} / \mathrm{a}$ & $\begin{array}{l}\text { Closure of Ryton, } \\
2,300 \text { redundancies }\end{array}$ \\
\hline GM-Vauxhall & Full CB & $95 \%$ & $\begin{array}{l}\text { Amicus/ } \\
\text { T\&G }\end{array}$ & No & $\mathrm{n} / \mathrm{a}$ & $\begin{array}{l}\text { Termination of shift, } \\
1,000 \text { redundancies }\end{array}$ \\
\hline Prudential & $\begin{array}{l}\text { Mixed - full } \\
C B / \text { no } C B\end{array}$ & $\begin{array}{l}56 \% \text { unionized } \\
\text { sites }\end{array}$ & Amicus & PEA & $\begin{array}{l}\text { Employee } \\
\text { Forum }\end{array}$ & $\begin{array}{l}\text { Closure of Belfast } \\
\text { and Bristol sites }\end{array}$ \\
\hline Aviva & $\begin{array}{l}\text { Limited } \\
\text { recognition/CB }\end{array}$ & $30 \%$ & Amicus & $\begin{array}{l}\text { Employe } \\
\text { Forum }\end{array}$ & Your Forum & $\begin{array}{l}\text { Organization-wide } \\
\text { restructuring }\end{array}$ \\
\hline Marconi & Full CB & $30 \%$ & $\begin{array}{l}\text { Amicus/ } \\
\text { T\&G/GMB }\end{array}$ & PEA & Forum & $\begin{array}{l}\text { Crisis, takeover, } \\
800 \text { redundancies }\end{array}$ \\
\hline Rolls-Royce & Full CB & $\begin{array}{l}100 \% \\
\text { (manual), } \\
70 \% \\
\text { (non-manual) }\end{array}$ & $\begin{array}{l}\text { Amicus/ } \\
\text { T\&G }\end{array}$ & PEA & $\begin{array}{l}\text { UK Information } \\
\text { and Consultation } \\
\text { Council }\end{array}$ & $\begin{array}{l}\text { No specific } \\
\text { initiative ongoing } \\
\text { restructuring }\end{array}$ \\
\hline
\end{tabular}

* Global Framework Agreement contained consultative mechanisms.

\section{Motor Vehicle Industry: Peugeot-Citroën and GM-Vauxhall}

The UK car industry has been transformed within two decades under the impact of intensified competition, changes in corporate structure and ownership and extensive geographical re-location. Foreign-owned firms now dominate the UK, with almost 
one-half of the $1.6 \mathrm{~m}$ cars produced in 2005 , manufactured by Japan's "big three" of Honda, Nissan and Toyota (Financial Times, 19/4/06). By 2006 Peugeot-Citroën had one remaining manufacturing plant, at Ryton, which employed 2,300. Production since 1999 had focused exclusively on the 206 model, and an indication of declining demand had been the decision to end the third " $C$ " shift in March 2005. By 2006 GM-Vauxhall's production, centred on the Astra (and small van variant), was confined to Ellesmere Port and a workforce of 3,000; the closure of GM's Luton plant in 2002 had sharply raised questions over Ellesmere Port's future.

At Ryton and Ellesmere Port, years of downsizing, closure threats, "whipsawing," lean production and European and global corporate and product strategies (Stewart et al., 2008) had profoundly shaped the character of employment relations. While the workforces at both plants had remained solidly unionized (T\&G majority, Amicus minority) and collective bargaining arrangements continued at national and plant levels, workplace organization inevitably had been weakened. Essentially a new politics of production prevailed in which, despite resistance and contestation particularly over pay, the unions had been compelled to accommodate to company demands over lean production, flexible working and productivity improvements. Stewart et al. (2008) demonstrate how at GM, through five successive company-union agreements, the promise of job security as the quid pro quo for flexibility and intensification proved illusory.

Neither Peugeot nor GM took specific initiatives in anticipation of the ICE Regulations. In Peugeot's case this neglect was not because the company was unaware of the potential implications following enforcement. Indeed, Amicus minutes of a special JNC meeting (24/03/05) to discuss termination of the " $\mathrm{C}$ " shift record Peugeot's HR Director stating that "the information and consultation legislation had nothing to do with the timing of this decision." In the view of the Amicus national officer, this amounted to a knowing avoidance of soon-tobe enacted Regulations. "They did not consult over the change [and] came to us with a decision ..." leaving the unions to negotiate only the voluntary redundancy package (Interview, 22/09/06). In GM's case, ICE was never "on the radar."

There were additional dimensions to consultation. Peugeot's Global Framework Agreement on Social Responsibility (Peugeot-Citroën, 2006a) promoted ten principles, including commitments on consultation and participation, particularly in respect of providing employees with regular and timely information on company operations and on issues affecting working conditions and employment. Employee participation initiatives were positively encouraged. This "global" commitment to social dialogue contrasts markedly with the absence of formal ICE arrangements in the UK. Insofar as consultation existed, it was confined to quality and quantity of production issues through monthly plant-level DCC meetings. Union officers in both companies contrasted the willingness to consult over productivity gains with restrictions on institutional access to strategic decision-making.

Both companies gave promises regarding their plants' immediate futures. In March 2005, Peugeot's Chief Executive J.-M. Folz offered a personal commitment to the unions that Ryton would, as a minimum, continue to produce the 206 on 
two shifts until 2010 (Amicus-TGWU, 2006) and Peugeot would consult over future plans. As late as January 2006 the Director of Corporate Communications had insisted that Peugeot "has a big industrial base in western Europe and there is no suggestion that we would shift that production" (JustAuto.com, 18/01/06). Ryton was "amongst the best of our plants" having made "tremendous improvements in productivity" and quality with "right first time [having] risen from 55\% to $78 \%$. Similarly, GM hailed Ellesmere Port's success; the Astra achieved number two in UK sales (2006), following huge improvements in quality and Ellesmere Port was top of GM's quality performance league (Weekly Team Brief, GM Manufacturing EP, 03/07/06). Despite these assurances, peremptory decisions of closure (Ryton) and large-scale redundancies (Ellesmere Port) followed shortly thereafter.

On 18 April 2006, Peugeot announced that production would end by mid-2007. Underpinning the decision was the building of additional capacity, equivalent to Ryton, with an investment of $€ 350 \mathrm{~m}$ at its new factory in Trnava, Slovakia. Production of the new 207 would commence in 2006 with other European plants fulfilling the outstanding requirements for the 206 . The dominant motive of cost reduction driving relocation is revealed in company figures estimating manufacturing costs at $€ 578$ per vehicle lower in Trnava than in Ryton (Peugeot-Citroën, 2006b). Comparative pay rates, extrapolated for 2010, were calculated at €9.52 per hour for Trnava and €32.44 for Ryton. Given that significant strategic relocation requires years of planning, Peugeot undoubtedly had disregarded the need to consult employees at an early stage.

Employees reacted with precisely the sense of shock that the Directive had been intended to obviate.

I found out on the radio on the way to work. Neither the union nor management told us anything. We're gutted. We'd heard rumours but no one had come out and told us what was happening, which makes me really angry (Alan Brown, Coventry Evening Telegraph, 19/04/06).

Such responses reflected the company's breach of promises to consult and the abrogation of its responsibilities under the Regulations. The company told national officers of "the decision taken not to source any new product into Ryton ... at the same time as they informed the workforce" (National Officer, 22/09/06). In further contravention of the Regulations, presenting this restructuring initiative as a fait accompli prevented alternative courses of action from being pursued. Although the unions developed a case (Amicus-TGWU, 2006) based on Ryton's profitability, comparative costs, social responsibility and flexibility, they were on the defensive, reacting to the "done deal" and striving unsuccessfully to persuade Peugeot to negotiate. The union also campaigned against Peugeot's disregard of ICE, lobbying Alan Johnson (Secretary of State for Trade and Industry) who had been responsible for enacting the Regulations.

Johnson's response is significant in exposing weaknesses in regulatory enforcement and government unwillingness to challenge corporate decision-making. Although Johnson attacked Peugeot for backtracking on its promises, and claimed to have "pressed M. Folz to ensure that the company abided by its obligations under information and consultation legislation... to maintain a meaningful and constructive 
dialogue with the Unions on their alternative plans" (Letter to unions, 26/04/06), his department's position was to emphasize that closure was "a commercial matter for Peugeot" (DTI News Release, 18/04/06). Following discussions with local politicians, regional development agencies and unions regarding the "implications of your announcement" Johnson reassured Folz,

I have made it clear to them, as I have in my public comments on the issue, the UK Government's appreciation that decisions such as this are ultimately a matter for the company (Letter, 20/04/06).

Thus, Peugeot's decision and the manner of its making were justifiable because of inviolable market forces. Meaningful employee consultation, even when backed by statutory force, was subordinated to corporate interests.

Paralleling developments at Peugeot, GM-Europe declared 1,000 redundancies at Ellesmere Port, cutting the third shift and reducing headcount to 2,000 (Financial Times, 12/05/06). The workforce immediately responded with walkouts and "wildcat" strikes as GM rejected last-ditch proposals by European unions to "spread the pain" across plants in Belgium, German, Poland and Ellesmere Port. Despite the long-term threat to Ellesmere Port, GM's rejection of the unions' strategy nevertheless surprised the T\&G and Amicus. A senior steward with over twenty-five years experience provided insight into the harsh consequences for UK employees of GM's "global" corporate strategy.

... there will never be a security of work agreement—how can there be? The unions will always find it hard to reach an agreement that actually protects, while the company is building more capacity into the eastern European plants - there is no agreement here ... They have just announced 700,000 capacity for two plants in Poland and Russia. Are the two plants for the eastern market only or for Europe as a whole? This is the contradiction in it all-take a shift out of Ellesmere Port because of overcapacity and at the same time build more capacity into the market. Scary stuff! (Interview, 04/04/06 cited in Stewart et al., 2008).

On 20 May, the Plant Manager wrote to all workers explaining that the decision was due to "capacity adjustment" as the "most cost-efficient approach," and that while there could be no guarantees of future production, failure to accept the redundancy programme would certainly lead to closure. Thus, in the period following the company's announcement, just as in the months when GM had formulated its plans, no meaningful discussion took place with the unions.

The company would say there was consultation, but we would say there wasn't. The consultation came after they made the decision. "We will have you in and this is what is going to happen." It was a consultation of how are we going to introduce it, how are we to get rid of people (Amicus officer, 16/11/06).

These were the circumstances that ICE was intended to prevent. Yet, in both cases, the objectives of ensuring that employees have access to company information and participate in consultation over proposed business changes proved elusive.

\section{Finance Sector: Prudential and Aviva}

A thoroughgoing transformation in the structure and dynamics of the financial services sector has also taken place in recent years. The Financial Services and Building Society Acts (1986) collapsed the distinctions between the banking, insurance and mortgage 
markets and precipitated trends to merger and acquisition (Morris et al., 2001). Prudential's takeovers included Scottish Amicable (1997) and M\&G (1999). Aviva was the re-branded name given to CGNU, the fusion of the Commercial General Union and Norwich Union (2000) both products of previous mergers. Driven by sector-wide intensified competition and pressures to maximize shareholder value, the Prudential and Aviva embarked on near-continuous programmes of restructuring, re-engineering and relocation aimed at slashing overheads and cutting costs. Central to these were technologically facilitated changes in the processes and loci of interactive servicing, notably the call centre's emergence as the dominant mode of customer contact (Bain and Taylor, 2002), and the digitalization of the back-office (Miozzo and Soete, 2001).

Both companies have been significant offshorers (Taylor and Bain, 2005). Without consultation, the Prudential decided to migrate 1,000 posts to Mumbai in September 2002 and to close its Reading call centre but, following a vigorous Amicus campaign, conceded to a three-year "no compulsory redundancies" agreement (AmicusPrudential, 2002). From late-2003 Aviva moved call centre and back-office posts to three Indian third-party suppliers, but from 2006 has transferred them to a wholly owned subsidiary, Aviva Global Services. By 2008, 7,800 jobs will be located in India (Norwich Union, 2006a). Thus, in terms of company strategy, restructuring within the UK has become inextricably connected to the expansion of offshoring. By mid-2006 Prudential, as the second largest UK life insurance and pensions provider, had more than 7 million customers and employed around 6,000. ${ }^{6}$ Aviva, the UK's largest and the world's fifth largest insurance company, employed 36,000 in its UK operations.

Prudential's industrial relations are dichotomous. While recognizing Amicus for collective bargaining at its Reading, Belfast, Bristol and London sites, where overall union density was 56\% (Interview seconded rep, 09/10/06), Prudential has resisted union attempts to extend recognition to Craigforth and Derby. Motivated by a desire to exclude Amicus, according to reps, the company continued at Craigforth to operate the paternalistic consultative body, the Employee Forum (EF), inherited from Scottish Amicable. The EF offered a soft consultative alternative potentially extendable across the company at the expense of Amicus and its reps network. Crucially, a divided workforce would weaken company-wide resistance to further restructuring. At Aviva, Amicus has a "Procedure and Facilities Agreement" giving representation rights, but is not accorded recognition for collective bargaining. This limited entitlement largely results from historical union weakness in Aviva's constituent companies. Further, the employers used merger to dilute the harder form of collectivism as represented by MSF-Amicus. The Norwich Union merger enabled management to recast industrial relations "from formal recognition to a partnership agreement which did not have recognition" (Interview seconded rep, 30/10/06).

Against this background of these attempts to reduce union influence, both Prudential and Aviva introduced ICE arrangements anticipating the ICE Regulations' enactment. Prudential established an "Employee Forum" with a written constitution through a PEA which conformed to the Regulations (Prudential, 2004). Although riddled with imprecision regarding the Forum's remit and its relationship to collective 
bargaining, the "Forum's Purpose" appeared unambiguous: providing elected representatives with "regular [bi-annual] updates on issues affecting the business and employees (para. 4.2), guaranteeing annual reviews [para. 4.3] and commitments to "consultation" and dialogue. Pessimistically, though, union reps perceived management's motivations as twofold: formal compliance with Regulations and weakening collective organization as Prudential pursued further restructuring and offshoring, following the ending of the job security agreement.

Aviva established "Your Forum" (YF) in November 2004 without workforce approval, claiming that with union density at $30 \%$, YF would provide representation for $70 \%$ of employees. Unsurprisingly, then, Amicus saw Aviva's legislative compliance as a further attempt to "sideline the union." YF's configuration reflected Aviva's organizational structure as separate forums were created for different businesses (e.g., Life Forum). From the beginning, union reps elected to the YF reported Aviva's unwillingness to engage in meaningful consultation (Interview national officer, 30/10/06).

Union suspicions regarding respective company motives regarding ICE initiatives were confirmed. On 26 April 2006, Prudential announced f40m cost savings, to be delivered by a "locational strategy" involving 700 redundancies, including the closure of Belfast and Bristol and job losses at London and Reading. The majority of the work would be transferred to Mumbai, but Craigforth would receive 200 jobs (Financial Times, 27/04/06). Compulsory redundancies were unavoidable. Amicus perceived this restructuring as anti-union as it involved transferring work from union-dense (Belfast $70 \%$ ) to non-union locations (Mumbai, Craigforth, Derby). During the period when Prudential was formulating plans, no attempts were made to inform the workforce, the union or the EF, let alone engage in the promised "dialogue and exchange of views and a debate undertaken in good faith." Amicus was verbally informed on 24 April, with written notification given on 26 April, 15 minutes before hastily arranged staff briefings, by which time news of the redundancies had already been made public.

Reps recalled how they had been presented with a fait accompli, although the company maintained that consultation was only beginning.

Certainly, what they said to us on the Monday was "This is a proposal, so the 90-day consultation period starts now." However, once you have announced to the staff and the wider world that something is going to happen then it is not really a proposal. And particularly once you have gone to the City, which they did on the Wednesday morning and explained the cost savings, it wasn't really consultation. To me, consultation should take place at the idea stage, so once they had an idea that they were thinking of closing Belfast down and needed to make cost savings, that's when they should have been talking to us (Senior seconded rep, 09/10/06).

Prudential's unilateral decision-making foreclosed the exploration of alternatives involving Amicus or EF representatives. Nevertheless, the union produced detailed counter-proposals (Amicus, 2006) based on similar cost savings, but without recourse to compulsory redundancies and Belfast's closure. Significantly, Prudential did not differentiate between the EF and Amicus in that neither established collective bargaining mechanisms nor were the new arrangements used to communicate with or involve employees. "There was no added level of consultation through the 
Forum as had been promised" (Senior seconded rep, 09/10/06). Ultimately, the EF's dependence on senior management rendered it incapable of acting on behalf of employees. This contrasted with Amicus' involvement in complex negotiations which led to Belfast's purchase by Capita, by which 450 jobs were transferred under the terms of the transfer of undertakings legislation (TUPE) (Capita, 2006).

Similarly, on 14 September Aviva announced 4,000 job losses (with 600 offshored) of which $50 \%$ would be compulsory redundancies. The rationale was the need to create a "leaner organization" delivering, for example, $f 125 m$ cost savings for the Life business (Norwich Union, 2006b). Amicus was informed of the decision "fifteen minutes before [it] was announced to the stock market." Where YF was concerned, Aviva strove, almost literally, to contain its ability to discuss, or reveal, details of the redundancies. Management had organized a Forum meeting on the day of the announcement which commenced at 8 a.m.

... a lot of the forum reps walked into that meeting and were flabbergasted because they didn't anticipate what was happening. They then more or less locked us into the room till 10 o'clock

... because the Stock Exchange were being told then ... They are using the excuse of the Stock Exchange, that they legally can't speak to us before they have spoken to them, but that's not true (seconded rep, 30/10/06).

As with the Prudential, Aviva claimed it was commencing "a programme of formal consultation" (Norwich Union, 2006a). However, as a rep insisted, "until you consult it should be a proposal" and the announcement was tantamount to an irrevocable decision.

Prudential and Aviva are typical of much of the financial services sector where unprecedented restructuring has resulted in wholesale redundancies. Rather than offering some protection for employees, even at the modest level of information provision, consultation initiatives appeared to be motivated by minimal regulatory compliance and the desire to constrain unions' ability to contest restructuring strategies. In both instances, the I \& C bodies spectacularly failed their first major tests. Reflecting on the broader significance of the Regulations, Aviva's national officer commented,

I guess ICE allows them to set up the forums. Having the forums allows them to sideline the union. And, having sidelined the union, when an announcement like the 4,000 job cuts is made, they don't have to engage with the union but, in reality, neither did they have to engage with the forums that they had set up.

\section{Electronics/Telecommunications Sectors: Marconi}

During the 1990s, the electronics company Marconi (formerly part of GEC) re-branded itself as a high-tech telecommunications specialist. Selling off stable revenue-generating sectors such as defence, it purchased extensively overseas (BBC News Online, 09/04/01). This strategic change proved disastrous, coinciding with over-capacity in telecoms markets, a worldwide slowdown and the burst of the dot.com bubble. As Marconi's major customers drastically reduced equipment budgets, the company's failure to diversify hit hard. Its value fell to $150 \mathrm{~m}$ from $\mathrm{f34bn}$ before the dotcom crash. Between 2000 and 2005 Marconi shed 20,000 jobs globally and shrank its UK workforce to 
4,300. A further massive setback was the failure in 2005 of British telecoms giant BT to include Marconi in the shortlist of suppliers chosen to develop " $21^{\text {st }}$ Century Network" (21CN) equipment, despite BT being Marconi's biggest and most significant customer. The share price plummeted at the news and major redundancies loomed. On 3 May 2005 the company agreed to consult the unions before any decisions were made but, on 6 May, it suddenly announced 800 redundancies and the closure of its Liverpool plant (The Guardian, 07/05/05). In October, Ericsson bought Marconi's operational side, retaining 3,000 workers in the UK. The small remainder of Marconi, re-named Telent, was reconfigured as a services provider for telecoms companies.

Across Marconi union membership had remained at around 30\%, with Amicus the major union and additional membership in the $T \& G$ and $G M B$, and the company had a long-established practice of site-based bargaining. Prior to 2005 there were no I \& C arrangements, not even a European Works Council (EWC), despite Marconi plants in Italy and Germany. ${ }^{7}$ Then, abruptly, in January 2005 Marconi announced that it was establishing a forum through the PEA route. Suspicions that union exclusion was the motivation were confirmed by the fact that only two weeks were allowed for representatives' nominations and elections. Unions were not consulted about the arrangements, nor given a written copy of the constitution. Since the Forum's fifteen constituencies were based on business units, the effect was to minimize unions' sitebased representation, locking the union into a minority of constituencies. It was only after the elections that Marconi presented a constitution to the forum using the post hoc signatories of its reps to claim workforce approval. The Amicus national officer insisted that the intention was to by-pass the unions.

They started to put company policies through this forum; not pay and conditions but they clearly were going to use it, not to get agreement, but to wave proposed policies in front of them. The only thing that stopped that happening was after April, and the whole future of Marconi ... then everything was blown out of the water (Interview, 29/11/06).

Significantly, the Forum was not warned of the forthcoming redundancies. Unlike Amicus which used its external profile and access to government departments and ministers,

... the information and consultation body itself was hardly involved at all in the serious issues. Very, very, superficial involvement. Ironically, we [the union] probably got more information from the company than the consultation body (Interview, 29/11/06).

A final issue concerns the non-disclosure of information, where the company cited confidentiality and the Stock Exchange rules as reasons. ${ }^{8}$ That Marconi's actions were taken for tactical rather than regulatory reasons is evidenced by the fact that anonymous briefings about likely bidders were given to the financial press.

They were using the press to say things they weren't telling the unions, the I \& $C$ body, or the workforce. So, when it was in their interests, they were quite happy to publicise stuff and give information out, not to the unions but the press to maximize their sale price (Interview, 29/11/06).

In sum, the introduction of a PEA with no prior consultation indicates minimal regulatory compliance and union marginalization. In the event, its establishment coincided with Marconi's crisis and it is noteworthy that the forum was not considered 
suitable for communicating with employees nor for discussing the implications for jobs of Ericsson's takeover. Evidently the Regulations made little impact on company actions in the wake of the company's crisis. Initial promises to consult were shortcircuited as Marconi decided unilaterally to close plants and enforce redundancies.

\section{Aerospace/Engineering Industry: Rolls-Royce}

Rolls-Royce is one of the two leading global suppliers of gas turbines and power systems for aircraft, marine and energy use. In 2005, the company employed 34,488 workers worldwide, nearly 21,000 in the UK. At its Bristol plant, this case study's locus, restructuring halved employee numbers to 4,000 between 1995 and 2005. Bristol has been subject to two salient drivers of change, emanating from a shifting economic environment characterized by intense global competition and the ability of customers to exert significant price reductions (Danford et al., 2005). Firstly, the plant was reorganized from a unitary division responsible for manufacturing military aero-engines into a more complex matrix structure of "customer-focused business units" (profit centres), deigned to reduce (particularly labour) costs. It created managerial pressure to fragment sitewide collective bargaining by devolution to these units (Danford et al., 2002). Secondly, management's "make-buy" strategy has involved downsizing and cutting labour costs by subcontracting key design and manufacturing work packages.

Collective bargaining arrangements were conventional as the manual and nonmanual unions divided into bargaining groups. Amicus dominated both and union density was 100\% and 70\% respectively (Interview convenor, 22/10/06). Discussions on policy issues, such as company strategy and staffing levels, were covered by multi-tiered consultative forums comprising bi-weekly meetings with HR managers, monthly meetings with the corporate director of operations, quarterly meetings of management and union representatives in the largest business unit, Defence Europe, and twice-yearly meetings of a Global Council. ${ }^{9}$ Meetings with HR managers and the director of operations were new informal forums arising from the implementation of a Modern Working Practices Agreement (MWPA). Full-time officers were excluded from all consultative committees except the Global Council, conditions regarded as restricting union influence (Full time officer, 22/10/06).

Immediately following the Regulations' enactment, Rolls-Royce established a UK Information and Consultation Council. Its remit was to provide early consultation on business issues affecting employees and to provide information and consultation, enabling opinions to be considered before decisions were reached (Rolls-Royce, 2006). Its terms of reference were agreed by a national negotiating committee of managers and senior union representatives prior to "technical" consultation with the workforce, but no ballot was held to endorse it. The Council included 29 employee representatives from the eight largest plants (all union nominees and virtually all shop stewards), plus three covering smaller sites.

Since the Council's institution there have been no redundancies in Rolls-Royce's UK plants to test the robustness of its founding principles of joint consultation and advance warning. Nevertheless, management has used the Council to engender a strategic shift 
attempting to change the locales of collective bargaining and replace bargaining with weaker consultation. Pursuing business-unit level bargaining on the micro-processes of policy implementation, such as MWPA, was accompanied by shifting discussions on terms and conditions (traditionally covered by site-wide collective bargaining) to the National Council. Management's ability to achieve this shift was partly aided by the unions having understandably placed less experienced stewards on the Council, seeing it initially as another burdensome layer of consultation. Consequently, management found it easier to ignore the consultation process completely when it suited them, or to raise issues governing changes to terms and conditions on the Council agenda, and once "consultation" had taken place to implement changes. ${ }^{10}$

Redundancy agreements and standardized conditions provide examples of management's attempt to use the National Council to replace plant-based negotiations with weak national consultation. The catalyst was the company's response to the Employment Equality (Age) Regulations 2006. It claimed that the existing redundancy agreement contravened the regulations by offering unequal terms dependent on age. Management sought to alter the agreement, in effect a change to terms and conditions, by raising the issue at National Council, rather than attempting formal negotiation with site unions. Similarly, management was seeking to effect inter-site standardization of non-pay related terms and conditions (sick pay and compassionate leave) by discussion at Council rather than through union negotiations. One convenor commented:

So they used the ageism document to change the redundancy document and they unilaterally just changed it without any reference back to us at all. It was all one way and HR blamed the UK Council. They said they consulted with them, but it was all one-way consultation, there was nothing coming back the other way. They just said they were going to use the ageism document even further to standardize sick pay schemes, leave of absence, to just standardize everything ... So our collective bargaining rights are going to disappear under that document (Manual convenor, 22/10/06).

However, union protestations forced the company to retreat and place the issue on the plant bargaining agenda. Given that the period since the forum's introduction has not seen the company propose redundancies, Rolls-Royce's consultative arrangements have not been subject to the most meaningful test of their effectiveness. Nevertheless, a clear pattern has emerged of attempts to exploit ICE in order to substitute national consultation for plant bargaining. Management suggests that the prospects are not favourable that Rolls-Royce will engage in meaningful consultation, when forthcoming restructuring initiatives occasion further redundancies.

\section{Conclusions}

The evidence presented exposes major faultines in the effectiveness of UK's ICE Regulations to provide employees with even the most limited protection against corporate plans to reorganize production and make wholesale redundancies. In five cases, companies failed to inform or consult with their employees regarding their future employment. Explicitly in three cases (Prudential, Aviva, Marconi), and potentially in 
another (Rolls-Royce), consultative arrangements provided opportunities to by-pass or undermine the union. In the finance sector, arrangements were introduced in part because of the coincidental need to weaken collective resistance to restructuring. In motor manufacturing, unions were simply ignored in circumstances where no consultative mechanisms had been established. In practice, companies treated unions and consultative forums with similar disdain. Contrary to management claims, ICEinspired mechanisms have not provided added levels of representation either to complement unions, or to fill the "representation gap" left by declining membership.

In all five cases involving job loss the workforces were presented with a fait accompli, in contravention of the supposed requirement that consultation should occur at the anticipatory stage. The Amicus officer for the electronics industry commented on this deficit.

Consultation, whether it's to do with redundancy or health and safety or broad information and consultation, is not meaningful unless the trade union and those representing the workforce have the opportunity and the ability to make the company reconsider its proposals. So my view is that, whether it's a trade union in its own right or an I\&C body, we should be involved at the "glint in the eye stage", before decisions are made—-before they've gone through the board or senior executive committee ... (Interview, 29/11/06).

This failure to consult raises wider questions about the wider political and legislative environment in the UK, where the law apparently allows companies peremptorily to make workers redundant. Amicus General Secretary Derek Simpson complained to Alan Johnson over Ryton's closure, that ministers were "limited in the support that they could give because they have created the regime which has allowed the company to behave like this" (The Times, 21/04/06); British workers were being sacrificed in the interests of maintaining "a flexible labour market" (The Guardian, 19/04/06).

Essentially, the Directive's transposition involved the "de-Europeanization" of the idea of worker consultation. In continental Europe, the development of consultative structures (e.g., works councils) has represented the idea that labour rights, such as joining a union or being consulted and informed, are basic human rights and an extension of the principles of democracy. The UK's failure is ultimately a political failure as the government opposed the ICE Directive in principle and, under the impact of employers' influence, produced Regulations that significantly diluted what, even in the original, were hardly radical proposals.

Growing union concerns regarding ICE should be rooted in a critical understanding of developments in UK employment legislation since 1997, which locate the ICE Regulations in Labour's subordination of its social-democratic heritage to neoliberalism (Smith and Morton, 2006). Not only are there limitations in the statutory union-recognition procedures of the Employment Relations Act, but Labour, despite its swift reversal of the Conservative's derogation of the "social chapter" of the Treaty of Maastricht (1992), has consistently remained sceptical of the European model of a regulated labour market. As Fairness at Work stated, "Some aspects of the social models developed in Europe before the advent of global markets have arguably become incompatible with competitiveness" (DTI, 1998: 10). Labour has continued 
policies of delaying and diluting EC Directives and then implementing them in a minimalist manner.

Clearly no amount of consultation or information will halt the process of capitalist reconstruction and relocation. However, the evidence from continental Europe shows that "Social Dialogue" in such circumstances can ameliorate the shock and allow a more ordered and negotiated transition in which unions and workplace reps can at least attempt to secure the best deal for their members. Given that ICE can be effective only insofar as the broader labour law regime allows, the "liberal" character of UK legislation places unions at a strategic disadvantage. Specifically, the absence of mechanisms of enforcement and of social and institutional deterrents leaves unions and the workers they represent vulnerable to companies' unilateral decisions. The Amicus officer for the motor vehicle industry observed of ICE that, "It's a dog with no teeth, it barks a lot but it ain't going to bite you if you are not frightened of it." All the trade unionists interviewed were emphatic that a reversal of policy and the restoration of collectivism are required to give workers some safeguards against the perpetual processes of corporate restructuring that increasingly jeopardize their livelihood. To date, the Regulations have failed to put an end to the sorry tales of workers hearing on car radios on their way to work that they have lost their jobs.

\section{Notes}

1 Non-EU readers should note that the European Union itself does not make law; the European Commission passes Directives which then have to be turned into national legislation (transposition) in the individual member states.

2 In 2008 Amicus completed its merger with the Transport and General Workers Union (TGWU) to form Unite.

3 Though, as we demonstrate, not in the case of Rolls-Royce.

4 The UK, Ireland and Italy were the only EU states lacking laws or legally-binding national agreements placing a duty on employers to inform and consult with employee representatives on economic and employment issues.

5 Initially applying to undertakings of 150 employees but extending to undertakings with at least 100 employees (6 April 2007) and 50 employees (6 April 2008).

6 It had $3 \mathrm{~m}$ additional customers at its internet-based operation Egg which employed 3,000.

7 As Amicus already represented Ericsson workers, the subsequent sale presented few organising problems. Ericsson had an I \& C body, although much weaker than its Swedish equivalent, and an EWC.

8 The UK's Advisory Conciliation and Arbitration Service (ACAS) makes it clear that Stock Exchange "Listing Rules" rarely justify a blanket restriction on information and consultation on commercial matters. They differentiate between employees and employee reps so that price sensitive information can be given to reps in confidence before the market is notified.

9 The Rolls-Royce PLC Global Council, established in 2005, replaced the hybrid EWC. According to the Convenor, consultation at GC did not offer meaningful union influence over company decision-making.

10 Interviews reveal several instances involving such as the use of agency labour, changes to a redundancy agreement, the standardisation of UK conditions, the payment of holiday pay to retirees and job transfers. 


\section{References}

ACAS. 2004. Guide to the Consultation and Information Regulations. London: ACAS.

Addison, J. T. and W. S. Siebert. 1992. "The Social Charter: Whatever Next." British Journal of Industrial Relations, 30 (4), 495-513.

Amicus. 2006. "Amicus Norwich Union Offshoring Briefing." September 2006.

Amicus-Prudential. 2002. "Amicus-MSF and Prudential UK and European Operations 14-Point Plan." 04/11/02.

Amicus-TGWU. 2006. "The Case for Ryton."

Bain, P. and P. Taylor. 2002. "Ringing the Changes? Union Recognition and Organisation in Call Centres in the UK Finance Sector." Industrial Relations Journal, 33 (3), 246-261.

Bain, P. and P. Taylor. 2008. "No Passage to India? Initial Responses of UK Trade Unions to Call Centre Offshoring." Industrial Relations Journal, 39 (1), 5-23.

Baldry, C. 1994. "Convergence in Europe: A Matter of Perspective?" Industrial Relations Journal, 25 (2), 96-107.

Barnard, C., S. Deakin and R. Hobbs. 2003. "'Fog in the Channel, Continent Isolated' Britain as a model for EU Social and Economic Policy?" Industrial Relations Journal, European Annual Review 2003, 461-476.

Blyton, P. and P. Turnbull. 2004. The Dynamics of Employee Relations. Basingstoke: Palgrave.

Capita. 2006. Belfast - Third Party Outsourcing Agreement, 15/08/06. London: Capita.

CBI. 2002. Response to: High Performance Workplaces: the Role of Employee Involvement in a Modern Economy. London: CBI.

CBI. 2004. Employers' Guide to the Law on Informing and Consulting Employees. London: CBI.

Cressey, P., C. Gill and M. Gold. 1997. "Industrial Relations and Social Europe: A Review." Industrial Relations Journal, European Annual Review 1997, 49-75.

Danford, A., M. Richardson and M. Upchurch. 2002. "Trade Union Strategy and Renewal: The Restructuring of Work and Work Relations in the UK Aerospace Industry." Work Employment and Society, 16 (2), 303-325.

Danford, A., M. Richardson and M. Upchurch. 2003. New Unions, New Workplaces: A Study of Union Resilience in the Restructured Workplace. London: Routledge.

Danford, A., M. Richardson, P. Stewart, S. Tailby and M. Upchurch. 2004. "High Performance Work Systems and Workplace Partnership: A Case Study of Aerospace Workers." New Technology, Work and Employment, 9 (1), 14-29.

Danford, A., M. Richardson, P. Stewart, S. Tailby and M. Upchurch. 2005. Partnership and the High Performance Workplace. Work and Employment Relations in the Aerospace Industry. Basingstoke: Palgrave Macmillan.

Danford, A., M. Richardson, V. Pulignano and P. Stewart. 2008. "Lean Production and Quality of Working Life on the Shop-Floor: The Experience of British and Italian Car Workers." Flexibility at Work: Critical Developments in the International Automobile Industry. V. Pulignano, P. Stewart, A. Danford and M. Richardson, eds. Basingstoke: Palgrave Macmillan.

Davies, P. and C. Kilpatrick. 2004. "UK Worker Representation after Single Channel." Industrial Law Journal, 33, 121-151.

DTI (Department of Trade and Industry). 1998. Fairness at Work: Cm 3968. London: DTI.

DTI (Department of Trade and Industry). 2002. High Performance Workplaces: the Role of Employee Involvement in a Modern Economy. London: DTI. 
DTI (Department of Trade and Industry). 2003. Workplaces: Informing and Consulting Employees. London: DTI.

DTI (Department of Trade and Industry). 2006. News Release. 18/04/06.

GM-Vauxhall Motors. 2006. Weekly Team Brief. Ellesmere Port 03/0706.

Hall, M. 2005. "Assessing the Information and Consultation of Employees Regulations." Industrial Law Journal, 34 (2), 103-126.

Hall, M. 2006. "A Cool Response to the ICE Regulations? Employer and Trade Union Approaches to the New Legal Framework for Information and Consultation." Industrial Relations Journal, 37 (5), 456-472.

Hall, M. and M. Terry. 2004. "The Emerging System of Statutory Worker Representation." The Future of Worker Representation. G. Healy, E. Heery, P. Taylor and W. Brown, eds. Basingstoke: Palgrave Macmillan, 207-228.

Hall, M. and P. Marginson. 2005. "'Trojan Horses or Paper Tigers?' Assessing the Significance of European Works Councils." Participation and Democracy at Work. B. Harley, J. Hyman and P. Thompson, eds. Basingstoke: Palgrave, 204-221.

Hall, M., A. Broughton, M. Carley and K. Sisson. 2002. Works Councils for the UK? Assessing the Impact of the EU Employee Consultation Directive. London: Eclipse.

Hayes, T. 2004. The Information and Consultation Directives: Strategic Choices and Experiences with EWCs. Belfast: Queen's University Belfast, Institute of Governance, Public Policy and Social Research.

Hyman, J. and B. Mason. 1995. Managing Employee Involvement and Participation. London: Sage.

Labour Research. 2000. "Don't bother telling the workers." June.

Labour Research. 2004. "Be organised, be consulted." November.

Miozzo, M. and L. Soete. 2001. "Internationalization of Services: A Technological Perspective." Technological Forecasting and Social Change, 67 (2), 159-185.

Moore, S., S. McKay and H. Bewley. 2004. "Employment Relations Research Series No. 26." The Content of the New Voluntary Trade Union Recognition Agreements, 1998-2002, vol. 1. London: DTI.

Morris, T., J. Storey, A. Wilkinson and P. Cressey. 2001. "Industry Change and Union Mergers in British Retail Finance." British Journal of Industrial Relations, 39 (2), 237-256.

Norwich Union. 2006a. Communications Pack: Cost and Efficiency Review. 13/09/06.

Norwich Union. 2006b. Cost and Efficiency Review: Final NUI Key Messages. 13/09/06.

Peugeot-Citroën. 2006a. Global Framework Agreement on Social Responsibility. Paris: Peugeot Citroën.

Peugeot-Citroën. 2006b. Cost Comparison of a New Vehicle Dedicated to Ryton and to Trnava. Paris: Peugeot-Citroën.

Prudential. 2004. Agreement Establishing the Prudential UK Employee Forum.

Ramsay, H. 1991. "The Community, the Multinational, its Workers and their Charter: A Modern Tale of Industrial Democracy?" Work, Employment and Society, 5 (4) 541-566.

Rolls-Royce. 2006. UK Information and Consultation Council Agreement. 10/01/06.

Smith, P. and G. Morton. 2006. "Nine Years of New Labour: Neoliberalism and Workers' Rights." British Journal of Industrial Relations, 44 (3), 401-420.

Stewart, P. and V. Wass. 1998. "From 'Embrace and Change' to 'Engage and Change': Trade Union Renewal and New Management Strategies in the UK Automotive Industry." New Technology, Work and Employment, 13 (2), 77-93. 
Stewart, P, M. Richardson, A. Danford, K. Murphy, T. Richardson, V. Wass. 2008. We Sell our Time No More': From Piece Work to Lean Production in the UK Automotive Industry since 1945. London: Pluto.

Streeck, W. 1994. "European Social Policy after Maastricht: The 'Social Dialogue' and 'Subsidiarity.'" Economic and Industrial Democracy, 15, 151-177.

Taylor, P. and P. Bain. 2001. "Trade Unions, Worker Rights and the Frontier of Control in UK Call Centres." Economic and Industrial Democracy, 22, 39-66.

Taylor, P. and P. Bain. 2005. "India Calling to the Far away Towns': The Call Centre Labour Process and Globalization." Work, Employment and Society, 19 (2), 261-282.

Taylor, P. and P. Bain. 2006. An Investigation into the Offshoring of Financial Services Business Processes. Glasgow: Scottish Development International.

Taylor, P. and P. Bain. 2008. "United by a Common Language? Trade Union Responses in the UK and India to Call Centre Offshoring." Antipode, 40 (1), 131-154.

Unison. 2005. Information and Consultation (April 2005) Factsheet. London: Unison Bargaining Support, http://www.unison.org.uk/acrobat/B1462.pdf.

\section{RÉSUMÉ}

\section{Un parapluie percé ? Restructurations d'entreprise, licenciements et efficacité de l'application au Royaume-Uni de la Directive européenne sur l'information et la consultation des travailleurs}

Notre article porte sur l'application au Royaume-Uni de la Directive de I'Union européenne relative à l'information et la consultation des travailleurs (ICT, en anglais «ICE »). Nous examinons les effets de cette mesure peu contraignante de gestion des ressources humaines dans le contexte impitoyable des restructurations, licenciements et fermetures d'entreprise. L'entrée en vigueur de la réglementation ICT au RoyaumeUni en avril 2005 a été présentée comme un progrès important en matière de droit de l'emploi et de relations du travail. Cette réglementation offrait en effet pour la première fois un cadre législatif accordant aux travailleurs le droit à l'information et à la consultation concernant l'emploi et les restructurations.

La fermeture précipitée par Renault de son usine de Vilvoorde en Belgique en 1997 a mis au jour des lacunes dans la législation européenne en matière de licenciements collectifs et de droits des travailleurs. C'est cela qui a poussé la Commission européenne à formuler cette Directive. La réglementation britannique a donc pour origine une tentative de l'UE d'empêcher les licenciements-chocs et d'encourager les entreprises à informer et à consulter les employés et leurs représentants sur les décisions majeures concernant leur emploi. Notre article permet de comparer les implications du type néolibéral britannique de marché du travail avec le modèle de marché social de l'Europe continentale. Les gouvernements travaillistes britanniques n'ont eu cesse de bloquer I'application de la Directive au niveau de I'UE, et ils en ont amoindri les effets puisque les employeurs ne sont plus obligés d'informer ni de consulter. La transposition de la Directive européenne a achevé d'en diluer l'effet.

La version finale de la réglementation britannique avait pour objectif non de donner plus de droits aux employés, mais d'intégrer le point de vue des employeurs, et 
plus particulièrement du syndicat patronal $C B I$, opposé à tout modèle participatif, et inébranlable dans sa volonté de maintenir la flexibilité du marché du travail. En conséquence, cette réglementation est peu contraignante et ne représente qu'une extension du contexte volontariste britannique où les intérêts des employeurs passent en premier. Certains vont jusqu'à avancer que la réglementation britannique ne fait que légitimer un mode de communication dont les syndicats sont exclus.

Notre étude porte sur le cas de six entreprises (Peugeot-Citroën, General Motors, Prudential, Aviva, Marconi, Rolls-Royce) issues de quatre secteurs (construction automobile, services financiers, électronique et aérospatiale). Nous examinons des entretiens approfondis et semi-structurés avec des syndicalistes, des cadres et des délégués syndicaux, ainsi qu'une abondante documentation concernant les entreprises et les syndicats. Nous avons choisi ces entreprises avant tout en raison de licenciements massifs postérieurs à l'entrée en vigueur de la réglementation britannique, et d'inquiétudes soulevées par le syndicat Amicus (devenu Unite).

Cet article met en lumière d'importantes failles dans l'efficacité de la réglementation ICT lorsqu'il s'agit de protéger les employés contre les entreprises qui réorganisent la production et licencient massivement. Cinq des entreprises n'ont ni informé ni consulté leurs employés. Dans trois cas sinon quatre, les dispositions consultatives ont carrément fourni à l'entreprise une occasion d'éviter de passer par le syndicat, sapant ainsi son influence. Dans le secteur des services financiers, l'introduction de dispositions inspirées de la réglementation ICT a contribué à affaiblir la résistance collective des syndicats aux restructurations et aux délocalisations. Dans le secteur automobile, où aucun mécanisme ICT n'avait été mis en place, on a carrément passé outre aux syndicats. Contrairement à ce qu'ont prétendu les employeurs, les dispositions ICT n'ont pas amélioré la représentativité en aidant le travail des syndicats ou en compensant le déclin du taux de syndicalisation. Dans les cinq entreprises qui ont effectué des licenciements, les employés ont été mis devant le fait accompli, en violation de la soi-disant obligation de les consulter à l'avance.

Ce manque de consultation soulève d'importantes questions sur le contexte politique et législatif britannique en général, où la loi semble permettre aux entreprises de licencier les travailleurs sans plus de façon. En fait, la transposition de la Directive revient à une " déseuropéanisation " du concept de consultation des travailleurs. L'échec du Royaume-Uni en la matière est d'ordre politique puisque le gouvernement a apporté une opposition de principe à la Directive européenne et a introduit une réglementation qui affaiblissait considérablement des propositions déjà peu révolutionnaires. Les inquiétudes exprimées par les syndicats devant la réglementation ICT trouvent leur origine dans une analyse critique de l'évolution de la législation britannique sur l'emploi depuis 1997, plaçant cette réglementation dans le contexte de la subordination par le parti travailliste de son héritage social-démocrate au néolibéralisme. Les gouvernements travaillistes n'ont fait que poursuivre la politique de leurs prédécesseurs conservateurs en freinant et en diluant l'efficacité de la Directive européenne, puis en l'appliquant de manière minimaliste.

Il va sans dire qu'aucune mesure de consultation et d'information ne peut stopper le processus de reconstruction et de relocation capitalistes. Ce qui se passe en Europe continentale montre cependant que le dialogue social peut amortir le choc et faciliter une transition négociée, où syndicats et représentants des travailleurs peuvent tenter d'obtenir de meilleures conditions. Le caractère « libéral » de la législation britannique 
met les syndicats en position de faiblesse stratégique. Plus particulièrement, l'absence d'un mécanisme de mise en application livre les syndicats et les travailleurs aux décisions unilatérales des entreprises. La réglementation ICT n'a pas réussi à empêcher que de malheureux travailleurs britanniques entendent sur leur radio d'auto en se rendant à leur travail qu'ils venaient d'être licenciés.

MOTS-CLÉS : Union européenne, information et consultation des employés, Royaume-Uni, fermeture d'usine

\section{RESUMEN}

\section{¿"Un paraguas lleno de huecos"? Restructuración empresarial, reducción de personal y eficacia de las regulaciones ICE}

Este artículo se interesa a la manera como la directiva de la Unión Europea sobre la información y la consultación de los empleados (ICE) ha sido empleada en el Reino Unido en las duras condiciones empresariales de restructuración, reducción de personal y cierre de fabrica. Basándose en entrevistas y material documentario de seis compañías (Peugeot-Citroën, general Motors, Prudential, Aviva, Marcono, Rolls Royce), el artículo presenta las principales fallas de eficiencia de las regulaciones ICE en el Reino-Unido para ofrecer una protección aunque sea limitada a los empleados que enfrentan la reducción de personal como un hecho consumado. Contrariamente a las alegaciones de la patronal, los convenios ICE no han procurado niveles adicionales de representación en complemento a los sindicatos ni un medio de cubrir el vacío de representación dejado por el deterioro de la cobertura. El fracaso de consultación plantea más amplias preguntas en el vasto contexto político y legislativo en el Reino-Unido.

PALABRAS CLAVES : Unión europea, información y consultación de empleados, Reino Unido, cierre de fabricas 